\title{
OIL IN TIMOR-LESTE: A TICKET TO PROSPERITY?
}

\author{
Jiří Sýkora*
}

\section{Introduction}

During the past few months, East Timor (officially Timor-Leste) celebrated the $10^{\text {th }}$ anniversary of its independence, inaugurated a former chief of the army as a new president in place of a Nobel Peace Prize laureate, elected a new parliament and announced the new 17-member cabinet. In stark contrast with past elections in Timor-Leste, all the 2012 ballots took place without any major incidents of violence. Today, active and retired domestic and foreign politicians are rushing with congratulations to each other as well as thanking the UNMIT (United Nations Integrated Mission in Timor-Leste) for support, using these (almost) incident-free elections as a main argument for UNMIT to leave the country before the end of 2012. At the same time, the international police forces UNPOL (United Nations Police), special military forces of the Portuguese army GNR (Guarda Nacional Republicana, National Republican Guard), as well as other foreign peacekeeping soldiers (mainly Australian) will make their exit and leave the country's security matters solely in Timorese hands. A few cautious voices are reminding others of the last withdrawal of international peacekeepers from Timor-Leste in 2005 that lead to subsequent unrest in 2006, widespread violence, attempted assassination of both president and prime minister, and a failed military coup. Democracy is still new and fragile in Timor-Leste but it is in the best interest of the 1.2 million ordinary citizens of this impoverished nation (see Table 1) for its leaders to overcome political differences and focus on resolving urgent challenges on the treacherous way to prosperity. Thanks to oil reserves, prosperity is a real possibility in Timor-Leste. But contrary to political voices praising peaceful elections as the ultimate achievement, the real work is now only beginning for Timor-Leste.

\section{Historical background}

The Island of Timor was colonized by the Dutch and the Portuguese from the beginning of the $18^{\text {th }}$ century and officially divided into Dutch West Timor and Portuguese East Timor in 1859. During World War II, the capital city Dili was under control of around 500 mainly Australian soldiers. After the Japanese invaded Timor, locals were supporting Australian soldiers in the mountainous interior and helped to save many of their lives before Australians eventually withdrew at the beginning of 1943 . After the war, Australia considered Timor-Leste to be of utmost strategic importance

\footnotetext{
* Timor-Leste (juve616@yahoo.com).
} 
and proposed defence cooperation to Portugal - who promptly declined. Twenty years later, Australia changed its position completely, Timor-Leste was seen as irrelevant and the Australian consulate in Dili was closed in 1971.

Following the Carnation Revolution in 1974, Portugal hastily withdrew from all its colonies. Unprepared, the newly independent countries often fell into a prolonged civil conflict with opposing sides supported by different cold war superpowers (for example, MPLA and UNITA in Angola, RENAMO and FRELIMO in Mozambique). TimorLeste gained independence in 1975 and when in the two months of internal conflict FRETILIN (Frente Revolucionária de Timor-Leste Independente, Revolutionary Front of Independent East Timor) beat its rival UDT (União Democrática de Timor, Democratic Union of Timor), the door to freedom and sovereignty seemed to be wide open. The same door was, however, brutally shut by Indonesia's full-scale military invasion on 7 December 1975. Indonesia simply ignored UN Security Council's Resolution 384 calling on all states to respect the territorial integrity of Timor-Leste and on Indonesia to withdraw its forces. Instead, Timor-Leste was annexed as the $27^{\text {th }}$ province of Indonesia. During the next 24 years of occupation, the official death toll on the Timorese side reached 183,000 (CAVR, 2005, p. 73) or a quarter of the total. All this with a silent approval from the most advanced democracies: US President Gerald Ford and Secretary of State Henry Kissinger visited Indonesia's President Suharto on 5-6 December 1975. Their intention was not to stop the invasion to Timor-Leste, which took place one day after their visit, but to ask Indonesia not to use US weapons and equipment in the process. Australia, on the other hand, had a long-term interest of its own: Timor-Leste's oil reserves.

\subsection{Timor Sea boundaries under Indonesian occupation of Timor-Leste}

Following World War II, President Truman proclaimed in September 1945 that the United States had jurisdiction and control over 'the natural resources of the subsoil and seabed of the continental shelf beneath the high seas but contiguous to the United States' (Cleary, 2007, p. 5). This marked the beginning of a race by coastal states to stake out their adjacent seas, oceans and seabed. In 1953, Australia made its own unilateral claim for continental shelf to a depth of 100 fathoms (about 200 metres). The United Nations, in turn, released the first Convention on the Continental Shelf in 1958, allowing coastal states to exercise sovereign rights over their continental shelf to a depth of 200 metres. To avoid disputes in areas adjacent to 2 or more coastal states, the Convention introduced a simple solution in the form of a median line that applies to overlapping claims (United Nations, 1958, p. 3): “[Article 6] Where the same continental claim is adjacent to the territories of two or more States whose coasts are opposite each other, the boundary of the continental shelf appertaining to such States shall be determined by agreement between them. In the absence of agreement, and unless another boundary line is justified by special circumstances, the boundary is the median line.” By signing the Law of the Sea Convention in 1958, Australia gained around 15 million square kilometres of sea area, almost double the size of the Australian landmass. Nevertheless, Australia also claimed that Article 6 cannot be applied in the Timor Sea between Australia and Timor-Leste because the two countries allegedly did not share the same continental shelf. 
In the Timor Sea, Australia's continental shelf extends from the Australian continent at a shallow depth of no more than 150 metres until it reaches the Timor Trough, about 300 kilometres from the Australian coastline. Australia claimed that this deep trough marked the border between two continental shelves, hence taking advantage of the fact that it lies less than 100 kilometres from the coast of Timor-Leste. From this position, Australia started to negotiate its maritime borders with Indonesia. Despite losing a significant maritime area, Indonesia signed the irreversible agreement with Australia under suspicious circumstances in 1972 (Map 1 shows the negotiated seabed boundaries as well as the median line where the border should have been drawn according to international law). Australia had attempted the same tactics when negotiating the border in the Timor Sea with Portugal. All such attempts failed, leaving a gap in the negotiated maritime borders, known as the Timor Gap. In 1978, Australia was the first country in the world to recognize Indonesia's sovereignty over Timor-Leste. This was directly linked to the negotiations over the Timor Gap that started between Australia and Indonesia at the beginning of 1979. However, Indonesia learnt from mistakes made in 1971/1972 and refused to accept Australia’s initial proposals.

\section{Map 1}

\section{Oil deposits and territorial disputes in the Timor Sea}

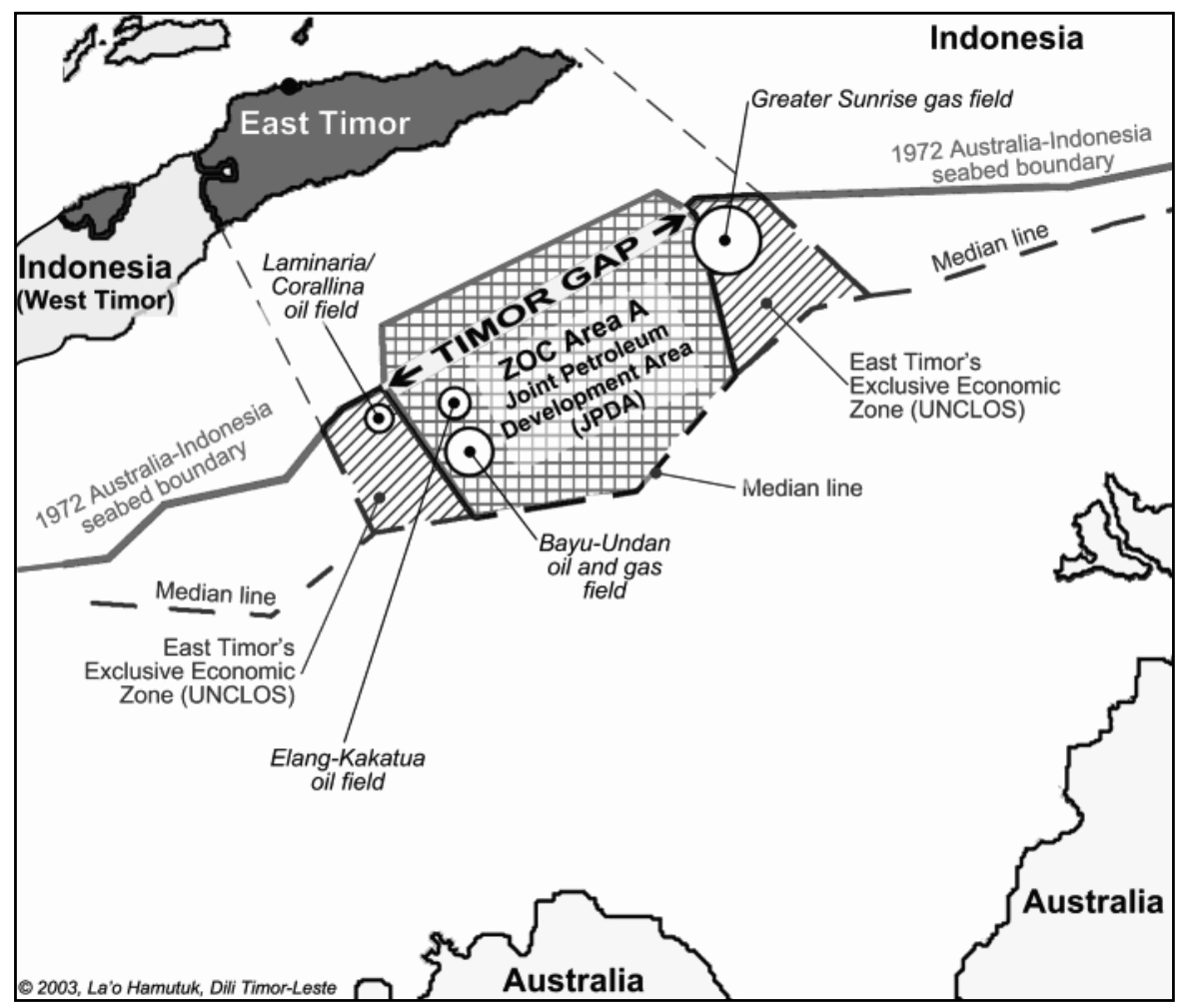

Source: Guteriano, Schneider, 2005, p. 7. 
This time, the negotiations over the sea borders dragged on for 10 years and only in 1989 did the two countries agree to close the Timor Gap by establishing a Zone of Cooperation in which the revenue from Area A was shared 50/50 between Indonesia and Australia (Map 1). Although not as successful as during the first round of negotiations in 1971/1972, Australia again achieved significant territorial gains. If the rule of the median line had been applied, the whole of Area A should have belonged to Indonesia. Smaller oil fields such as Elang-Kakatua started to be developed by Australia’s biggest resource company BHP Ltd immediately. Elang-Kakatua started producing in 1998 with revenue split between Indonesia and Australia. This money legally belonged to Timor-Leste but its representatives abroad could do little more than complain (Horta, 1998, p. 1).

\subsection{Independent Timor-Leste, Australia's new partner for negotiations}

After the Asian economic crisis brought the fall of Suharto in May 1998, there appeared first real signs that Timor-Leste might achieve independence. It was in Australia's interest to keep Timor-Leste under Indonesian rule but the new Indonesian President Habibie opted for an immediate ballot on the territory's future. In August 1999, nearly 99\% of the Timorese took part in the Popular Consultation and $78.5 \%$ of them voted for independence. Indonesian-backed militias immediately unleashed widespread violence, killing at least 1500 people. Australian-led UN peacekeeping forces were deployed to oversee the departure of the Indonesian army and Timor-Leste's development under UN Transitional Administration of Timor-Leste (UNTAET). The first democratic parliamentary elections were held in August 2001, giving 55 out of 88 parliamentary seats to FRETILIN (Marí Alkatiri, who had spent the period of Indonesian occupation in exile, mainly in Mozambique, became the first Prime Minister). The resistance fighters' leader Xanana Gusmão was elected the first President of Timor-Leste in April 2002 and UNTAET officially handed over the country's administration to the first government on 20 May 2002. Timor-Leste became the $191^{\text {st }}$ member state of the United Nations in September 2002. However, Australia was not going to soften its stance and continued fighting for natural resources in the Timor Sea from an unchanged position of power.

In 2000, representatives of the Australian Government visited Dili and presented to UNTAET, which included future Timorese leaders as well as international experts, their request that independent Timor-Leste honour all agreements previously negotiated with Indonesia. This would mean that Timor-Leste would effectively receive only a $20 \%$ share of the natural resources situated on its side of the Timor Sea. This request was not accepted, Timor-Leste opting for not becoming a successor state and not inheriting Indonesia's legal obligations. Instead, Timorese leaders made public declarations that Timor-Leste would never allow the current practice to continue and that perhaps it could settle for a $90 \%$ share of the Timor Sea resources instead of $50 \%$ (Lague, D., 2000, p. 7). After tough negotiations in Canberra in June 2001, it was eventually agreed by the Timor Sea Treaty that Timor-Leste was to receive a $90 \%$ share of Area A only (now called the Joint Petroleum Development Area, JPDA). This meant that Timor-Leste would get only $18.1 \%$ of the total revenue from the Greater Sunrise field 
(as 79.9\% of the field's area lies outside the JPDA, Timor-Leste would receive $90 \%$ of the $20.1 \%$ lying inside the JPDA). A separate contract was drawn for the Greater Sunrise area - the International Utilization Agreement (IUA). The new agreements met with fierce opposition in Timor-Leste, especially because the Greater Sunrise field is the biggest prize in the Timor Sea with an estimated 300 million barrels of oil and 7.7 trillion cubic feet of gas. It is also situated closest to Timor-Leste's coast among all the currently known oil fields, but Timorese leaders planned to ask for more during negotiations for permanent maritime boundaries after their country became independent.

\subsection{Final agreement?}

Australians were well aware that the newly independent Timorese state needed resources to function and could not afford not to sign the Timor Sea Treaty. It would mean going back to the historic 50/50 arrangement from Area A only, which would not bring enough money for the new state to function. At this point, Australia refused to negotiate anything further until the IUA was signed by Timor-Leste. Timor already signed the Timor Sea Treaty but Australia did not, putting more pressure on Timor to sign the IUA first and claiming that if Timor did not sign, the resources might stay in the ground for the next 20 to 50 years. The new Timorese government was clearly going to be totally dependent on the revenue from the Bayu-Undan field situated in the JPDA, which was the first to start producing, but without having the Timor Sea Treaty signed by Australia, none of the international oil companies were going to invest in the field's development. That is why Timor-Leste signed the IUA in March 2003. Australia followed by signing the Timor Sea Treaty in April 2003 and the Bayu-Undan development went ahead.

Now it was Timor's time to play hard for the Greater Sunrise field. Even though the IUA was signed by Timorese leaders, it would have to be ratified by the parliament to come into effect. Development of the Greater Sunrise area could not start without that and Timor used this leverage to make Australia negotiate permanent maritime borders in the Timor Sea. Nevertheless, Australia started to advertise licences for oil fields in the disputed Greater Sunrise area. Timor-Leste focused on warning potential investors not to buy licences and not to invest in the disputed areas as well as on trying to win public opinion internationally and in Australia. Timor-Leste refused several Australian offers, notably a \$3 billion cash settlement for Greater Sunrise paid over 30 years, and the countries eventually reached a final Treaty on Certain Maritime Arrangements in the Timor Sea (CMATS). It divides 50/50 the revenue from the Greater Sunrise fields and defers maritime boundary claims for 50 years. The CMATS entered into force in February 2007 after it was passed by the Parliament of Timor-Leste.

During the 6 years of negotiations between 2000 and 2006, Timor-Leste managed to secure almost a three-fold increase in its resource control and revenue from the Timor Sea, from $22 \%$ in 2000 to $60 \%$ in 2006 . Estimates on the absolute value of the revenue vary but today it is accepted that Timor-Leste has managed to increase its total income from over $\$ 8$ billion to over $\$ 24$ billion in 40 years (Cleary, 2007, p. 264). On top of that, there is a possibility for a further increase as new or bigger oil reserves are found 
- as was the case with the Bayu-Undan field when new discovery increased its reserves by $25 \%$ in 2006 . Not all Timorese leaders are happy with the $50 / 50$ solution, claiming that Timor-Leste could have achieved $100 \%$ of Greater Sunrise. In any case, these negotiations serve as a strong example and future reference of a small poor country dealing with a great external as well as internal pressure and standing for its rights.

Today, Bayu-Undan remains the only source of oil revenue for Timor-Leste; the field will probably be exhausted in 2023. That is why development of the Greater Sunrise area is so important for Timor-Leste. However, no final agreement was reached with regard to its development and it remains to be seen when Greater Sunrise starts producing. Currently, two disputed issues related to Timor's oil and gas remain to be resolved: firstly, Timor-Leste wants to build a pipeline from Greater Sunrise to its southern shore, and bring all the gas to be processed in a new factory to be built. In the meantime, Australia prefers a "floating processing" solution on site. This is not a small issue as according to several estimates the potential revenue from Greater Sunrise gas processing exceeds that from sales of its oil reserves. Secondly, there is the issue of oil companies paying correct amounts of tax. Timor-Leste started to scrutinise the accounting of the oil companies in detail in 2009 and in 2010 it successfully claimed $\$ 32.4$ million in back payment of taxes. The oil companies developing the Bayu-Undan field (Conoco Phillips of the USA, Santos of Australia, and Inpex of Japan) had inflated the recoverable costs of their operations, hence decreasing the tax base and consequently the tax amounts paid to Timor-Leste. Another case of a similar nature is being processed in the second half of 2012 with Timor-Leste claiming potentially up to $\$ 2$ billion in unpaid taxes.

\section{Timor-Leste today}

Not surprisingly, after its violence-stricken past, Timor-Leste currently occupies the bottom places of most international comparisons - result of numerous problems awaiting resolution in current Timorese society. According to the UNDP, Timor-Leste currently belongs to the group of low human development countries (with a Human Development Index value of 0.495 ), occupying the $147^{\text {th }}$ position on the list of 187 . Table 1 shows a selection of the few statistical indicators available for Timor-Leste demonstrating the magnitude of the tasks ahead. 


\section{Table 1}

\section{Selected social indicators, Timor-Leste 2011}

\begin{tabular}{|l|r|}
\hline Population total (million) & 1.2 \\
\hline Median age (2010, years) & 16.9 \\
\hline Population in severe poverty (\%) & 38.7 \\
\hline Life expectancy at birth (years) & 62.5 \\
\hline Mean years of schooling (years) & 2.8 \\
\hline Adult literacy rate (\% ages 15 and older) & 50.6 \\
\hline Deaths due to water pollution (per million people) & 308.0 \\
\hline Deaths due to malaria (per million people) & 48.2 \\
\hline Deaths due to dengue (per million people) & 35.0 \\
\hline Total fertility rate & 5.9 \\
\hline Adolescence fertility (births per 1,000 women aged 15-19) & 65.8 \\
\hline Births attended by skilled health personnel (\%) & 18.0 \\
\hline Maternal mortality ratio (per 100,000 live births) & 370.0 \\
\hline Mortality under 5 (per 1,000 live births) & 56.0 \\
\hline Population under age 5 suffering from stunting (\%) ${ }^{1}$ & 55.7 \\
\hline Population under age 5 suffering from wasting (\%) ${ }^{2}$ & 40.6 \\
\hline
\end{tabular}

Source: UNDP, 2011.

${ }^{1}$ Percentage of children under age 5 below the median height-for-age of the reference population.

${ }^{2}$ Percentage of children under age 5 below the median weight-for-height of the reference population.

Now that the political situation seems to have stabilised, the country needs to rapidly address the pressing problems typical of most post-conflict and under-developed countries: ensure peace and security, adopt a modern legal system and make justice accessible to all its citizens, build physical infrastructure and human capital, make quality education, health and social services available to all. Also, according to the World Economic Forum's Global Competitiveness Report 2011-12, inadequate infrastructure is the most problematic factor for doing business in Timor-Leste. The country ranks $138^{\text {th }}$ from 142 countries and occupies the very last position in several partial indicators (interestingly, in 'Diversion of public funds due to corruption' Timor-Leste occupies the $89^{\text {th }}$ place compared to the $124^{\text {th }}$ for the Czech Republic, WEF, 2011, p. 392). The remaining infrastructure was largely destroyed in the 1999 conflict. Today, one third of the population has no access to improved drinking water, $60 \%$ lack decent sanitation facilities, and two thirds are living without electricity. Around 90\% of the roads are in a poor condition and seaports, airports, and telecommunications need urgent improvements. These problems should be tackled using Timor-Leste's oil revenue, which requires its effective and transparent management. 


\section{Theoretical framework for effective management of natural resource revenue}

At present, there are numerous countries in the world that strongly depend on oil for revenue; in most cases, their oil reserves are expected to be depleted within 30-40 years. Given the volatility of crude oil prices, it is very important for such countries to find a balance between immediate spending and saving for future generations. Generally speaking, the main target should be ensuring long-term sustainability of fiscal policies. Unfortunately, politics often get in the way of wise economic management and resource-rich countries fall victims to a resource curse. As an unwelcome consequence, the quality of the average person's life in countries such as Congo, Nigeria, or Angola is lower than in countries without natural wealth (Sachs and Warner, 1997, p. 3).

Very few resource-rich countries are currently using their wealth as a blessing - United Arab Emirates or Botswana have invested oil and diamond revenue, respectively, in modern infrastructure and education. However, most of the other resourcerich countries suffer from a number of potential problems: exporting natural wealth negatively impacts the quality of domestic institutions, leads to widespread corruption and nepotism and effectively becomes an obstacle to economic growth (Oomes and Kalcheva, 2007, p. 7). Moreover, politicians tend not to improve ineffective policies and indebt their nations excessively. When the natural resources are exploited, the country plunges into a serious financial and economic crisis. Another potential problem is creation of overly generous systems of social security that will not be sustainable after the natural resources are exploited. Politicians might also face pressure to protect domestic companies from external competition, especially in the context of real exchange rate appreciation (Dutch disease theory). Restrictive trade policies then in turn negatively impact long-term economic development (Arezki and Van der Ploeg, 2007, p. 4). Various studies (Leigh and Olters, 2006, p. 3) confirm that in periods of high oil prices, state budgets of oil exporters are in an overall surplus but, at the same time, in a very deep deficit if oil revenue is excluded. If the foreign reserves of such a country are high enough, its economy is not immediately threatened but with oil reserves closer to depletion, high non-oil deficits become unsustainable.

Countries with large (but exhaustible) oil reserves may falsely believe that no budget restrictions apply to them. High oil revenue leads to political pressure to maximize immediate spending. The same level of spending cannot be maintained if world oil prices fall or the volume of oil production decreases. It also leads to creation of vested interests and dependency of many economic subjects on ineffective government spending. In the context of overall budget surplus, this makes fiscal consolidation rather difficult. Exactly in such situations, it is desirable to have a clear indicator that could be used to evaluate long-term sustainability of fiscal policies. This instrument could help policy-makers as well as the general public differentiate between desirable and sustainable policies and government decisions aimed only at satisfying short-term needs. It would be ideal to implement such an instrument before the start of oil production, before unwanted habits are formed. The instrument must enable prevention of sharp falls in government spending at times of falling oil production and/or falling oil prices. Abundance of oil resources is a serious problem for macroeconomic policy 
and politicians must decide on consumption today and tomorrow. Because of negative experience of sharp decreases in government spending and their economic and social consequences in the recent past, the majority of governments today understand that long-term sustainability of fiscal policy should be a priority. Sustainability is achieved by implementation of fiscal rules that restrict fiscal policy to a certain extent. The efficiency of fiscal sustainability could measured in the long-term using various indicators. At present, it is generally accepted that the best indicators for countries exporting oil are indicators assessing the state budget (deficit) excluding oil revenue (Segura, 2006, p. 11).

Final decision on concrete fiscal rules always depends - to some extent - on the country's specific conditions such as the relative sizes of its oil and non-oil sectors, the phase of oil production, or the general level of economic development. There is no one best fiscal rule that would be applicable in all cases and that would ensure long-term fiscal sustainability. Different countries have tried to implement different solutions. One extreme is the "balanced budget rule", where the complete oil revenues are spent immediately while the state budget is balanced. This solution is theoretically sustainable in the long term but gives complete preference to present over future generations. It can also lead to extreme fluctuations of government spending. The opposite extreme is the "bird-in-hand" policy, in which only the interest income accruing from accumulated oil revenues is spent consistently over time. While this policy mostly avoids the boom-bust spending cycle of the balanced budget rule, and is obviously fiscally sustainable, it may create social tensions because public spending would be low while oil revenues are being accumulated during the period of oil exploitation. Between these two extremes are several other fiscal rules, among them constant expenditure rules, rules that target a price of oil and save any revenues generated by prices above that threshold, and rules that save a fixed percentage of oil revenues. The oil windfall not spent in these cases can be allocated to savings or stabilization funds, or both, to smooth out fluctuations in annual government spending. A useful theoretical framework, with desirable intergenerational considerations, is the Permanent Income Hypothesis (PIH), formulated by Milton Friedman in 1957. According to the PIH, both individuals and governments should be considered forward-looking, trying to smooth consumption over time in line with permanent income. Where there is zero population and productivity growth, the PIH implies constant government consumption out of oil revenue over time that is equal to the annuity present value of the expected oil wealth. By definition, expenditures out of oil proceeds would be stable, thus avoiding boom-bust cycles. The added predictability that this rule offers should in principle help policymakers avoid bottlenecks in absorptive capacity (Meghir, 2004, p. 9).

Several countries have implemented fiscal rules trying to ensure permanent income levels for future generations. Expert opinions on such measures differ, not least because of the objective difficulties predicting future oil prices as well as defining exactly the levels of any country's oil reserves. Some (Takizawa, Gardner, Ueda, 2004, p. 19) have criticized the use of the PIH in managing oil wealth, especially by developing countries: when the initial capital of the economy, both physical and human, is low, the productivity gains of government social and capital spending of oil revenues could exceed the financial returns from oil savings. This can happen where there are production externalities from government spending, particularly from the impact of public investment 
on productivity and the incentives it generates for private capital accumulation. Under these circumstances, it could be advisable to frontload the use of oil resources. Future generations, though enjoying fewer oil resources for their own consumption, would benefit from the build-up of capital in the form of better public services, improved living conditions (health and basic education), and enhanced human capital.

Absorptive capacity constraints are often used as an empirical counterargument to the excessive frontloading of spending, which may result in inefficiency and waste of resources. Some countries have already implemented stabilization funds with mixed results. Only in countries such as Norway, Kuwait, or Oman have stabilization funds met their expectations. Problems encountered in other countries included excessively rigorous rules of deposits and withdrawals from the fund. A country then could not withdraw money from the fund even though it needed to finance deficit of its state budget. Stabilization funds often do not withstand political pressures to overuse their resources at times of growing world oil prices. Politicians tend to think that in such circumstances it is not necessary to manage oil funds strategically. Depleted funds then cannot perform their function when world oil prices decrease. In some cases, stabilization funds have adopted certain functions of state budgets; for example, projects for reconstruction of physical infrastructure were financed directly from the fund. Despite all the potential problems, there is general agreement that correctly managed stabilization funds contribute to a stable macroeconomic environment (Shabsig and Ilahi, 2007, p. 16).

\section{Managing oil resources in Timor-Leste}

In 2009, Timor-Leste became the first country in South East Asia declared EITIcompliant. The Extractive Industries Transparency Initiative (EITI, www.eiti.org) is a coalition of governments, companies, civil society groups, investors, and international organizations. Its goal is to implement a global standard ensuring transparency of payments from natural resources in order to help especially developing countries overcome the resource curse and achieve economic progress. Strict EITI rules and procedures make it the most prestigious and internationally recognized initiative to increase transparency in resource-rich countries. EITI membership can positively influence the investment climate in a country because it proves that the government works openly. As of October 2012, there are only 15 EITI-compliant countries, 20 candidate countries, and one suspended country. Timor-Leste was accepted as an EITI-compliant country on 1 July 2010. The status must be revalidated within 5 years (by 1 July 2015) or at any earlier point if any of the Timorese stakeholders or the EITI deem necessary. By being EITI-compliant, Timor-Leste clearly indicates political will to use its oil revenues transparently and to the best possible effect for the general public. That is also why, in cooperation with the international community, Timor-Leste has implemented several instruments to achieve transparency and fiscal sustainability. 


\subsection{Petroleum Fund}

Timor-Leste's Petroleum Fund (PF) was established in 2005 by the Petroleum Fund Law (Law No. 9/2005), which is the centerpiece of Timor-Leste's resource management. It is essentially a government account with the Central Bank (Banco Central de TimorLeste) to which the country's petroleum receipts are credited and from which debits can be made to finance the state budget. The original PF Law defines the Estimated Sustainable Income (ESI) as 3\% of Timor-Leste's total petroleum wealth defined as the current PF balance plus the net present value of future petroleum receipts. This is the sustainable income from petroleum wealth - the amount that can be spent in the current year and in every year in the future, without prejudicing future generations. For example, the 2012 ESI is estimated at \$665 million. The ESI is calculated every year based on a conservative set of assumptions on petroleum output and prices and reflecting international best practices and recognized international standards. The oil prices used in ESI calculations are derived from the US Energy Information Administration (EIA) forecast for low-sulphur light crude oil, consistent with West Texas Intermediate, a key benchmark international oil price. The price forecast used is the average of the EIA low and reference case from the 2011 Annual Energy Outlook, which is \$74 per barrel for 2012. This price is well below the World Energy Outlook price assumption of $\$ 100$. Only volumes from projects with approved development plans and firm investment commitments (i.e., the Bayu-Undan field) have been included in the ESI calculation. The Greater Sunrise field has been declared a commercial discovery but does not yet have an approved development plan. Therefore, Sunrise is not included in the ESI although it is a confirmed petroleum resource.

Timor's PF is modelled on Norway's successful oil fund, which was launched in 1996, had $\$ 250$ billion in assets in 2006 and reached $\$ 600$ billion in 2011. TimorLeste's fund is designed to avoid the pitfalls of natural resource wealth by investing offshore in low-risk government bonds and by spending only the sustainable income from petroleum wealth. Investing safely is of fundamental importance, which is why, until 2011, a minimum of $90 \%$ of the fund's assets must have been invested in US government bonds. This decision had its critics in Timor-Leste who argued that in effect Timor-Leste was financing the US war in Iraq. (Also, since Timor-Leste adopted USD as its currency, there is a danger of depreciation of the US dollar, raising domestic inflation and reducing the purchasing power of the Timorese.)

Until 2007, Timor-Leste was not able to spend anywhere near the ESI limit because of low absorption capacity and poor planning. The government excelled at saving but did less well when it came to spending and investments. However, government expenditure has increased sharply since then. As a consequence, the Petroleum Fund Law was amended in 2011 to allow higher investment in equities (up to 50\% of the $\mathrm{PF}$ ) and for the PF to be used to secure government borrowing (up to $10 \%$ of the PF). As of September 2011, the PF was composed 88\% by US government bonds, $4 \%$ other government bonds (AUS, EU, UK, JP), 4\% US \$ foreign government and supranational, and $4 \%$ global equities. Some experts see this as necessary to secure enough cash for the government's future spending; others are unhappy that the original strict rules of PF management are weakening. 


\subsection{Institutions managing the oil sector in Timor-Leste}

According to the PF Law, the main building blocks in the management of the PF are the Parliament, the Government, the Central Bank (CB) and the Ministry of Finance (MoF). Other important functions are held by the external investment managers, the Investment Advisory Board (IAB), the PF Consultative Council, the independent auditor, the Director of Treasury, and the Ministry of Petroleum and Mineral Resources (previously the Secretariat of State for Natural Resources). In 2008, 2011 and 2012 respectively, the National Petroleum Authority, a national oil company and the Institute of Petroleum and Geology were established.

The overall management of the fund lies with the Government, which submits annual reports and is accountable to the Parliament. Monies can be withdrawn from the PF to fund government budget expenditure but this requires approval from the National Parliament and the money can only move from the fund to the budget. During the analysis and approval process, the Parliament is advised by the PF Consultative Council. The PF Consultative Council is comprised of 20 representatives from Government, former heads of the CB, former Members of Parliament, civil society, private sector, religious organizations and former Presidents of the Republic. The PF Consultative Council is funded through the state budget.

The operational management of the fund lies with the CB (previously Banking and Payments Authority) based on a management agreement between the MoF and the CB. To execute its duties, the CB established the PF Management Department in August 2005, headed by an Executive Director accountable to CB Governor. The Governor of the CB is appointed by the Prime Minister. The CB holds an earmarked receipts account and submits quarterly reports to the MoF. The CB invests the fund's capital according to guidelines established by the MoF. The CB is entitled to deduct reasonable management expenses as per the management agreement. The MoF is required to seek advice from the IAB before any decision related to the investment strategy or management of the PF is made. The IAB comprises the Director of Treasury, the Governor of $\mathrm{CB}$ and at least three other persons appointed by the Prime Minister. The independent auditor, an internationally recognized accounting firm (currently Deloitte), selected and appointed by the Government, reports on the PF receipts to the MoF. The Director of Treasury, appointed by the Minister of Finance, maintains the PF accounts in accordance with international accounting standards and reports quarterly to the MoF. Externalinvestmentmanagersareappointedby theCBandapproved by the MoF to invest defined amounts of the PF. Currently, the Bank for International Settlements, appointed as an external investment manager in 2009, manages 20\% of the fund and Schroder Investment Management Limited, appointed in 2010, is the equity manager for $4 \%$ of the fund.

Other institutions do not directly participate in management of the PF but are vital to the overall management of the oil sector in Timor-Leste: the Ministry of Petroleum and Mineral Resources (previously the Secretariat of State for Natural Resources) is the Government body coordinating all matters related to the country's natural resources. The National Petroleum Authority (ANP - Autoridáde Nacional do Petróleo) is responsible for managing and regulating petroleum activities onshore, in the Timor- 
Leste exclusive offshore area and in the joint petroleum development area (JPDA). Timor-Leste's national oil company, Timor GAP, was established for purposes of holding and managing the assets owned by the State in the petroleum sector and to participate in any petroleum operations. The Institute of Petroleum and Geology (IPG) is the third, and last, of the organizational and administrative structures required for efficient use of petroleum resources under the umbrella of the Ministry of Petroleum and Mineral Resources. Its main mission is the compilation, processing, selection, filing, reproduction and dissemination of information on petroleum, gas and mineral resources.

\subsection{Using oil revenue in Timor-Leste}

The first government of Timor-Leste proved to be ineffective. Ministers often stayed overseas, central controls were made strong and, as a result, only half of the $\$ 120$ million 2005/2006 state budget was actually spent. Timor-Leste consists of 13 districts but the district administrations were each given a budget of \$2,000 per month only (Cleary, 2007, p. 76). Prime Minister Alkatiri was unpopular for his domestic policies (as well as his Muslim religion in a Christian country) but managed to find an external enemy - Australia - to keep him in seat. He was well aware of the dangers that natural resources can mean for a country's development, and critically contributed to the setting up of Timor-Leste's Petroleum Fund. However, he failed to spend the resources available and there was very little physical development during the first four years of independent Timor-Leste. Alkatiri was increasingly accused of nepotism, making sure that the vast majority of public contracts were attributed to the wide network of companies created by members of his extended family. Eventually, he was forced to resign in 2006 following civil unrest and widespread violence. Under the new Prime Minister Xanana Gusmão, Timor-Leste started to increase government expenditure in the name of the country's reconstruction. This has supported strong economic growth but also drove inflation into double digits. At present, international institutions recommend that Timor-Leste slows down the planned increase in its capital spending to better align with the absorptive capacity of the economy and administrative constraints. While the government spent \$268 million on capital in 2010, capital expenditure jumped to \$718 million in 2011 and a planned \$1,078 million for 2012(IMF, 2012, p. 4). Timor-Leste is using the US dollar as its national currency, hence the main emphasis lies on fiscal policy. The country is still building and improving its weak administration and government institutions and launched a Strategic Development Plan (SDP) in 2011. This document shows the way the government wants to transform the country from a low-income to an upper-middle-income country by 2030. The SDP aims for rapid, inclusive growth by improving infrastructure, worker skills, education, training and health systems, and by combating malnutrition. 


\section{Table 2}

\section{Selected economic indicators}

\begin{tabular}{|c|c|c|c|c|c|c|}
\hline & 2007 & 2008 & 2009 & 2010 & 2011 & $\begin{array}{l}2012 / \\
\text { Est. }\end{array}$ \\
\hline Real sector & \multicolumn{6}{|c|}{ Annual \% change } \\
\hline Real non-oil GDP growth & 11.7 & 14.6 & 12.8 & 9.5 & 10.6 & 10.0 \\
\hline CPI (annual average) & 10.3 & 9.0 & 0.7 & 6.8 & 13.1 & 8.0 \\
\hline CPI (end-period) & 8.6 & 7.5 & 1.7 & 9.2 & 12.9 & 8.0 \\
\hline Central government operations & \multicolumn{6}{|c|}{ In $\%$ of GDP, unless otherwise indicated } \\
\hline Revenue & 75.4 & 80.8 & 72.5 & 75.2 & 78.1 & 72.6 \\
\hline Domestic revenue & 2.7 & 1.7 & 2.5 & 2.6 & 2.6 & 3.3 \\
\hline Petroleum revenue & 72.6 & 79.1 & 70.0 & 72.6 & 75.6 & 69.3 \\
\hline Expenditure & 13.5 & 19.6 & 23.8 & 24.8 & 28.0 & 34.8 \\
\hline Recurrent expenditure & 8.8 & 13.5 & 15.4 & 16.5 & 13.0 & 16.7 \\
\hline Capital expenditure & 4.8 & 6.1 & 8.4 & 8.4 & 15.0 & 18.1 \\
\hline Overall balance & 61.8 & 61.2 & 48.7 & 50.4 & 50.2 & 37.9 \\
\hline $\begin{array}{l}\text { Non-oil overall balance } \\
\text { (in \% of non-oil GDP) }\end{array}$ & -39.6 & -85.3 & -71.1 & -81.1 & -104.0 & -102.2 \\
\hline Balance of payments & \multicolumn{6}{|c|}{ In millions of US dollars, unless otherwise indicated } \\
\hline Current account balance & 1177.0 & 2023.0 & 1363.0 & 1538.0 & 2375.0 & 1773.0 \\
\hline (in \% of GDP) & 65.1 & 66.7 & 51.7 & 48.1 & 55.0 & 43.5 \\
\hline Trade balance & -169.0 & -297.0 & -376.0 & -374.0 & -666.0 & -795.0 \\
\hline $\begin{array}{l}\text { Exports (excl. petroleum } \\
\text { exports) }\end{array}$ & 7.0 & 14.0 & 9.0 & 18.0 & 22.0 & 33.0 \\
\hline Imports & 176.0 & 311.0 & 385.0 & 392.0 & 689.0 & 829.0 \\
\hline Petroleum revenue & 1313.0 & 2400.0 & 1845.0 & 2323.0 & 3261.0 & 2821.0 \\
\hline Overall balance & 147.0 & 20.0 & 39.0 & 156.0 & -3.0 & 160.0 \\
\hline Public foreign assets (end-period) ${ }^{1}$ & 2316.0 & 4407.0 & 5627.0 & 7310.0 & 9743.0 & 11487.0 \\
\hline (In months of imports) & 158.0 & 170.0 & 175.0 & 224.0 & 170.0 & 166.0 \\
\hline GDP at current prices & 1808.0 & 3035.0 & 2634.0 & 3199.0 & 4315.0 & 4073.0 \\
\hline Non-oil GDP & 494.0 & 635.0 & 790.0 & 876.0 & 1054.0 & 1252.0 \\
\hline $\begin{array}{l}\text { Oil GDP (Petroleum revenue } \\
\text { used as proxy) }\end{array}$ & 1313.0 & 2400.0 & 1845.0 & 2323.0 & 3261.0 & 2821.0 \\
\hline Petroleum Fund balance & 2086.0 & 4197.0 & 5377.0 & 6904.0 & 9338.0 & 10923.0 \\
\hline $\begin{array}{l}\text { Petroleum Fund balance } \\
\text { (\% of non-oil GDP) }\end{array}$ & 422.0 & 661.0 & 681.0 & 788.0 & 886.0 & 872.0 \\
\hline Public debt & 0.0 & 0.0 & 0.0 & 0.0 & 0.0 & 43.0 \\
\hline
\end{tabular}

Source: IMF, 2011.

${ }^{1}$ Composed of the Petroleum Fund balance and the Central Bank’s official reserves. 
Apart from oil, the country exports very little except coffee (coffee exports reached \$20 million in 2011 and an estimated \$30 million in 2012). Imports of food are stable at around \$50 million per year; the majority of imports are manufactured goods as virtually nothing is produced locally. The key risks for Timor-Leste's development at present are a potential sharp decrease in world oil prices, high inflation due to high government spending that could push back the progress on poverty reduction and hurt the growth of the private sector, and limited progress on plans to improve the government institutions, which could undermine public financial management and reduce the effectiveness of large public investment. The government is encouraged by the international community to continue focusing on reduction of its non-oil fiscal balance over the next 10 years. Timor-Leste continues to enjoy a low risk of debt stress despite undertaking higher borrowings - the Parliament approved, for the first time, a concessional borrowing of \$43 million in 2012 from the World Bank, the Asian Development Bank and bilateral donors to finance infrastructure projects.

Despite all the improvements, the administrational capacity of Timor-Leste's government remains very weak and it is likely that the public system will be unable to manage and control all the reconstruction projects efficiently. Probably at least part of the public money will be wasted unless the new government revises future state budgets to allow for a more gradual increase in capital expenditure. The outgoing government was very strongly criticized for using more than the recommended level of the ESI for state budgets (3.8\% in 2009, 4.8\% in 2010, 4.3\% in 2011, and a planned $7.2 \%$ in 2012). While this is not contrary to the Petroleum Fund Law, critics are pointing out that it does not make sense to jeopardize future generations' capital when the country simply cannot cope with such a sharp increase in its capital expenditure. Prime Minister Gusmão unintentionally proved their point during his address to the Parliament, when he admitted that as of 10 October 2012, only 49\% of the 2012 state budget was executed. At the same time, he asked the Parliament to approve a 2012 budget rectification. While the amount of total budget expenditures did not change, it was necessary to make considerable changes to the individual budget chapters, using some of the funds originally planned for infrastructure projects (now delayed at least until 2013) mainly to implement new social benefits for war veterans and pensioners (Timor Post, 2012, p. 1). While the introduction of social benefits in Timor-Leste's current situation is desirable, the budget rectification also points out a more important problem: inefficient planning and execution of infrastructure reconstruction projects.

The government makes infrastructure development Timor-Leste's prime target, focusing on electricity, roads, and the rural housing program. It is also investing in infrastructure on the South Coast to attract investment in the downstream petroleum sector. Timor-Leste cooperates closely with the international community, recognizes the potential problems of a sharp increase in government spending, and implements new measures to better manage large public investments. In 2011, the Infrastructure Fund (IF) was set up to facilitate the development of large, multi-year projects. The Secretariat of Major Projects at the MoF was given responsibility for reviewing projects proposed by line ministries, and the final approval is decided either by the Board of the IF (for projects worth less than $\$ 5$ million), or by the Council of Ministers. The National Development Agency was established to supervise project 
implementation, and the Procurement Commission to assist in the procurement for large scale projects undertaken by the IF. Infrastructure spending is mainly to be financed by withdrawals from the Petroleum Fund but there are considerations to also increasingly use borrowing and public-private partnerships.

While the plans of the new government for possibly reviewing future capital expenditure plans are not yet known, it has already been criticised from the very beginning for wasting public money. The new government consists of the Prime Minister, 16 ministers, 11 vice ministers, and 25 secretaries of state. In total, the new government has 53 members compared to the 40 members of the previous one. Some of the civil society members are calling the new cabinet the "government of oligarchy" because six ministries are headed by brothers and sisters. Moreover, the new government has already managed to make several controversial decisions: buying brand new luxury cars for each of the ministers, proceeding with purchase of military boats of questionable quality (from the same vendor who supplied four patrol boats for marine police a few years ago; three of them are permanently out of service), or deciding to purchase one tank from Indonesia to allegedly improve domestic security. Before the public, these details can overshadow the government's good work in other areas and do little to improve the perception of corruption in Timor-Leste. According to Transparency International's Corruption Perception Index, the country was $143^{\text {rd }}$ out of 182 evaluated in 2011.

\section{Summary}

Timor-Leste is one of the poorest countries in the world where half of the population is illiterate, one in 20 children dies before reaching the age of 5 , and the average person attends school for less than three years. The country faces many socio-economic challenges and its government must put the natural resources to a good use, develop the country, and make it a safer and more pleasant place to live than it is today. In many resource-rich developing countries, the inflow of revenue from exports of oil and other mineral resources has crippled their economic development by inflating their exchange rates and making other export sectors uncompetitive. These receipts financed inflationary spending on grandiose projects that turned into white elephants or the latest military hardware. Timor-Leste has adopted the US dollar as its domestic currency; its fiscal policies become all the more important. Even before the country's independence, its leaders were well aware of the domestic human capital limitations. Their openness, political courage (for example, the MoF is sometimes scorned as the "ministry of foreigners" because of the high number of foreign consultants it hires) and willingness to cooperate with the international community have brought concrete results: democratic institutions in place, working processes defined, compliance with EITI, and others. Thanks to all this, Timor-Leste has made a good start on the way to effective management of its resources and rapid development of its economy.

The policy of saving a significant proportion of its resource wealth has been a challenging objective in a post-conflict country where people have seen a great deal of death in their immediate families and communities. The notion of saving for the future in these circumstances can be an alien concept but the country's leaders 
have overcome this. However, present-day Timor-Leste seems to be at a crossroads: the sheer existence of instruments and institutions must be complimented with strict enforcement of the rules defined. Several recent incidents might indicate that these rules are being loosened a bit: the change to the Petroleum Fund rules and inefficient and unnecessary spending of public money can undermine the future development process. Today, Timor-Leste is in the same situation where many other resource-rich countries have failed. So far the country manages its oil wealth wisely and has made a good progress towards building a modern society from scratch. But in order to succeed, the good work must continue in the years ahead.

\section{References}

AREZKI, R.; VAN DER PLOEG, F. Can the Natural Resource Curse Be Turned Into a Blessing? The Role of Trade Policies and Institutions [IMF Working Paper WP/07/55]. Washington, DC : IMF, 2007.

BARTSCH, U. How Much Is Enough? Monte Carlo Simulations of Oil Stabilization Fund for Nigeria [IMF Working Paper WP/06/142]. Washington DC : IMF, 2006.

CLEARY, P. Shakedown, Australia's Grab for Timor Oil. Allen Unwin, Crows Nest, 2007. ISBN 978-174114-926-5.

COMMISSION FOR RECEPTION, TRUTH, AND RECONCILIATION (CAVR). Chega! The Report of the Commission for Reception, Truth, and Reconciliation Timor-Leste. Dili, Timor-Leste : CAVR, 2005.

Corruption Perception Index 2011. Berlin : Transparency International, 2011. ISBN 978-3-943497-18-2.

DELOITTE. Timor-Leste Extractive Industry Transparency Initiative Report, 31 December 2009. Dili, 2010. http://eiti.org/countries.

GUTERIANO, N.; SCHNEIDER, C. Oil in Timor-Leste. Dili : La'o Hamutuk, 2005. www.laohamutuk.org/ Oil/curse/OillnTLOilwatch.htm.

HORTA, R. CNTR Statement on Timor Gap Oil. New York : ETAN, 1998.

Human Development Report 2011. New York : UNDP, 2011. ISBN 9780230363311.

INTERNATIONAL MONETARY FUND. Democratic Republic of Timor-Leste: 2011 Article IV Consultation [IMF Country Report No. 12/24]. Washington, DC :IMF, 2012.

LAGUE, D. Timor Plea to Revise Oil Treaty. Sydney Morning Herald. 2000, 8 May, p. 7.

LEIGH, D.; OLTERS, J. P. Natural-Resource Depletion, Habit Formation, and Sustainable Fiscal Policy: Lessons from Gabon [IMF working paper WP/06/193]. Washington, DC : IMF, 2006.

MEGHIR, C. A Retrospective on Friedman's Theory of Permanent Income [WP04/01]. London : The Institute for Fiscal Studies, 2004.

OOMES, N.; KALCHEVA, K. Diagnosing Dutch Disease: Does Russia Have the Symptoms? [IMF Working Paper WP/07/102]. Washington, DC : IMF, 2007.

REPÚBLICA DEMOCRÁTICA DE TIMOR-LESTE. Strategic Development Plan 2011-2030. Dili : Governo de Timor-Leste, 2011. www.tls.searo.who.int/LinkFiles/Home_NATIONAL_STRATEGIC_DEVELOPMENT_PLAN_2011-2030.pdf.

SACHS, J. D.; WARNER, A. M. Natural Resource Abundance and Economic Growth [NBER Working Paper No. 5398]. Cambridge, Mass. : National Bureau of Economic Research, 1995.

SEGURA, A. Management of Oil Wealth under the Permanent Income Hypothesis: The Case of São Tomé and Príncipe [IMF Working Paper WP/06/183]. Washington, DC : IMF, 2006.

SHABSIGH, G.; ILAHI, N. Looking Beyond the Fiscal: Do Oil Funds Bring Macroeconomic Stability? [IMF Working Paper WP/07/96]. Washington, DC : IMF, 2007. 
TAKIZAWA, H.; GARDNER, E. H.; UEDA, K. Are Developing Countries Better Off Spending Their Oil Wealth Upfront? [IMF Working Paper WP 04/141]. Washington, DC :IMF, 2004.

The Global Competitiveness Report 2011-2012. Geneva : World Economic Forum, 2011. ISBN 978-9295044-74-6.

TIMOR POST. Primeiro Ministro Apresenta Coresaun Orsamentu 2012 iha Parlamentu Nasional. Timor Post. 2012, 12 October.

UNITED NATIONS. The Convention on the Continental Shelf. Geneva : United Nations, 1958. http:// untreaty.un.org/cod/diplomaticconferences/lawofthesea-1958/lawofthesea-1958.html.

\section{OIL IN TIMOR-LESTE: A TICKET TO PROSPERITY?}

Abstract: Timor-Leste is currently the third newest member state of the United Nations, independent since 2002. It is also one of the poorest places on earth where life is extremely difficult: after prolonged fighting, physical infrastructure is virtually nonexistent, services such as health and education are of a low quality and not accessible in the mountainous interior, and a big part of the population lives in extreme poverty scraping just enough to survive. However, all this might change during the next decade(s). Timor-Leste not only has many problems but also a powerful tool for their solution: oil and gas reserves in the Timor Sea. Timor-Leste has had to fight just as hard for the rights to exploit its natural resources as it was fighting for its independence. Many pressing socio-economic problems are awaiting resolution but the country can use over $\$ 10$ billion of oil revenue to address them. Institutions and instruments have been set up for efficient management of Timorese oil resources, but will the government really manage to spend the country's wealth wisely?

Keywords: international law, public administration, management of oil resources

JEL Classification: E22, F51, H54 